\title{
A Review of Activities \& Plans for Solar Energy in Federal Buildings
}

October 1980

Prepared for:

U.S. Department of Energy

Assistant Secretary Conservation

and Solar Energy

Office of Solar Applications for Buildings

Under Contract No. AC01-79CR10001 


\section{DISCLAIMER}

This report was prepared as an account of work sponsored by an agency of the United States Government. Neither the United States Government nor any agency Thereof, nor any of their employees, makes any warranty, express or implied, or assumes any legal liability or responsibility for the accuracy, completeness, or usefulness of any information, apparatus, product, or process disclosed, or represents that its use would not infringe privately owned rights. Reference herein to any specific commercial product, process, or service by trade name, trademark, manufacturer, or otherwise does not necessarily constitute or imply its endorsement, recommendation, or favoring by the United States Government or any agency thereof. The views and opinions of authors expressed herein do not necessarily state or reflect those of the United States Government or any agency thereof. 


\section{DISCLAIMER}

Portions of this document may be illegible in electronic image products. Images are produced from the best available original document. 


\section{NOTICE}

This report was prepared as an account of work sponsored by the United States Government. Neither the United States nor the United States Department of Energy, nor any of their employees, makes any warranty, express or implied, or assumes any legal liability or responsibility for the accuracy, completeness, or usefulness of any information, apparatus, product, or process disclosed, or represents that its use would not infringe privately owned rights. Reference herein to any specific commercial product, process, or service by trade name, mark, manufacturer, or otherwise, does not necessarily constitute or imply its endorsement, recommendation, or favoring by the United States Government or any agency thereof. The views and opinions of authors expressed herein do not necessarily state or reflect those of the United States Government or any agency thereof.

\footnotetext{
Ava1lable from:

Nat1onal Technical Information Service (NTIS)

U.S. Department of Commerce Springfield, Virginia 22161

Price: Printed Copy: $\$ 6.00$ Microfiche: $\quad \$ 4.00$
} 


\section{DOE/CR/10001-72

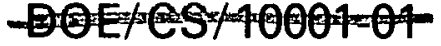 \\ Dist. Category UC-59}

\section{A Review of Activities \& Plans for Solar Energy in Federal Buildings}

October 1980

Prepared for:

U.S. Department of Energy

Assistant Secretary Conservation

and Solar Energy

Office of Solar Applications for Buildings

Prepared by:

Computer Sciences Corporation Systems Division

Vienna, Virginia

Under Contract No. AC01-79CR10001

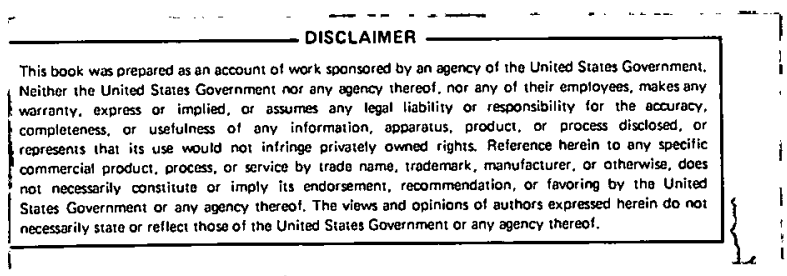


List of Tables and Figures................................. 1

List of Acronyms.........................................

EXECUTIVE SUMMARY......................................111

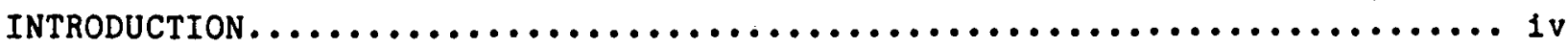

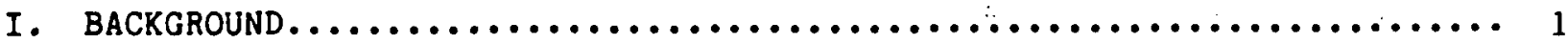

A. Guidelines For Preparation of the Ten Year Buildings Plans......... 1

B. Functions of the $" 656 "$ Committee.......................... 2

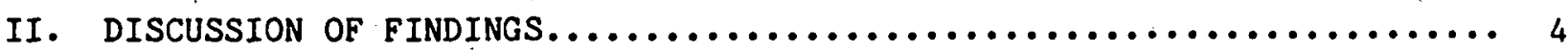

A. Guidelines For Preparation of Ten Year Buildings Plans.......... 4

1. Goals in the Building Plans......................... 4

2. Incorporating Ongoing Plans....................... 5

3. Programs to be Planned........................... 8

4. Retrofit Program for Existing Federal Buildings............ 9

5. Design Program For New Federal Buildings................... 13

B. Summary of Supplemental Solar Data........................ 15

C. Report of "656" Comittee Activities Regarding Solar Energy ....... 15

III. CONCLUSIONS AND RECOMMENDATIONS $\ldots \ldots \ldots \ldots \ldots \ldots \ldots \ldots \ldots \ldots \ldots \ldots \ldots \ldots$

Footnotes

Bibliography 


\section{LIST'OF TABLES AND FIGURES}

Number

$I I-1$

II-2

II-3

II -4

II-5

II -6

I I I - 1

III-2
Title

$\underline{\text { Page }}$

Agency Funded Solar Heating, Cooling,

6 and Hot Water Projects in Federal

Buildings FY 1975 - FY 1980

DOE Agency Jointly Funded Solar

6

Heating, Cooling, and Hot Water

Projects Under the Solar Heating and

Cooling Demonstration Program FY 1975

- 1980

Federal Agencies Plans For Solar

Heating, Cooling and Hot Water Systems FY 1981-FY 1985

DOE Solar Federal Buildings Program

Projects

Agency Owned Existing Buildings

Inventory and New Buildings Plans FY 1981-FY 1985

Federal Agency Estimates of Number of

Programs and Dollars That Could be

Requested From SFBP.

LIST OF FIGURES

Comparison of Federal Agency Existing

and Planned Solar Heating, Cooling, and

Hot Water Projects

Comparison of Funds Appropriated in FY

1.980 Under the SFBP Versus Agencies 


\section{LIST OF ACRONYMS}

DOC

DOD

DOE

EPA

FCC

FEMA

GSA

HHS

DOI

DOJ

DOL

NASA

NSF

USDA

USPS

DOS

DOT

TVA

TREAS

VA

NECPA

EPCA
-Departmént of Commerce

-Department of Defense

-Department of Energy

-Environmental Protection Agency

-Federal Communications Commission

-Federal Emergency Management Agency

-General Services Administration

-Department of Health and Human Services

-Department of Interior

-Department of Justice

-Department of Labor

-National Aeronautics and Space Administration

-National Science Foundation

-United States Department of Agriculture

-United States Postal Service

-Department of State

-Department of Transportation

-Tennessee Valley Authority

-Department of Treasury

-Veteran's Administration

-National Energy Conservation Policy Act

-Energy Policy Conservation Act 


\section{EXECUTIVE SUMMARY}

This report reviews Federal agencies activities and plans for the use of solar energy in Federal buildings. Based on this, recommendations are made for planning of the DOE's Solar Federal Buildings Program.

The report is based upon (1) an analysis of Federal agencies Ten Year Buildings Plans regarding solar energy (2) supplemental data, and a review of the activities undertaken by the "656" Committee regarding solar energy.

The Ten Year Buildings Plans were submitted to the DOE by Federal agencles owning or leasing Buildings. The plans are prepared as part of an Overall Energy Management Plan and will be incorporated into the President's Ten Year Plan for Energy Conservation in Buildings. The DOE published, in November 1979, "Guidelines for Ten Year Buildings Plans." The Guidelines specified plan content, submission date, and performance goals and objectives that are to be adopted by the agencies and stated in their plans. Twenty agencies were required to submit plans. Seventeen have been received to date.

Five sections of the Guidelines specified requirements for inclusion of solar and renewable energy data. The data to be included in the agency plans deal with the following areas: goals for solar and renewable energy, incorporating ongoing plans, programs to be planned, retrofit program for existing Federal buildings, and design program for new Federal buildings. Supplemental solar data was requested of agencies. They were requested to provide an estimate of the number of solar systems they would like to undertake if more dollars were available under SFBP. Close scrutiny of agency compliance with the requirements revealed the data submitted in the buildings plans was fragmented, contradictory, and lacking in precision, due to the first attempt in developing such a plan. Data inconsistencies were resolved, to the extent possible, through supplemental data and telephone conversations with agency representatives. The "656" Committee provides coordination of inter-departmental Federal Energy Management activities. The committee is composed of senior level representatives of twelve Federal agencies. Six Working Groups were established by the committee to generate energy saving actions that could be implemented quickly. One of the areas addressed was the use of solar energy in Federal Buildings.

Analysis of Ten Year Buildings Plans

A review of the agencies' plans submitted in compliance with the Guidleines indicated the following with respect to solar energy activities and plans:

- Agencies have installed 206 solar heating, cooling and hot water systems at a cost of $\$ 34$ million with their own funds through FY 1980. The Department of Defense has funded the largest number of systems, 70 , at a cost of 23 million. All other agency investments total approximately $\$ 11$ million for 136 system agencies. Agencies are planning, between FY 1981 and FY 1985 , to install an additional 125 systems at a cost of about $\$ 46$ mililion to meet the 1985 energy reduction goal. DOD is planning 84 systems.

- Indications are that agencles are not planning a large number of solar projects in existing buildings because of competition with other more 
cost effective energy conservation opportunities, and the need to conduct more thorough investigation of the potential for solar in buildings. All agencies stated they would give preference to solar in their buildings consistent with the life cycle costing guidelines. However, several agencies indicated little contribution is expected from solar and renewable energy sources by 1985 , due to its unattractive life cycle costs. According to several agencies, the 10 percent discount factor used in the current life cycle costing methodology limits the potential for solar and renewable energy applications. Specifically, it is limited by the funding competition with other more cost effective energy conservation opportunities.

- Agencies consider new buildings to have the greatest potential for installation of solar and renewable energy systems. All agencies will install at least one active or passive solar or other renewable energy system in new buildings when such systems are cost-effective in accordance with the guidelines. Some agencies will install more than one active or passive system.

- All agencies have participated in either the DOE's Solar Heating and Cooling Demonstration Program or are participating in DOE's Solar Federal Bulldings Program. The DOE, under its Solar Heating and Cooling Demonstration Program, has funded about 59 solar systems at a cost of approximately $\$ 7.8$ million. Sixteen Federal agencies have recently been awarded a total of $\$ 31.14$ million to install 843 solar systems. Several agencies stated in the Buildings Plans that they are eager to obtain additional funds from. DOE. to install additional solar systems. Supplemental Solar data, requested by the Office of Solar Applications for buildings. also idicated that agencies would like to receive funds to undertake an additional 2,737 solar projects at a cost of $\$ 143$ million.

Review of "656" Committee Activities Regarding Solar Energy in Federal Buildings

One of the "656" Committee Working Groups addressed the use of solar energy in buildings. The suggestion was made to take a position on advocating solar energy in buildings. Many negative reactions were received. One of the significant reactions dealt with the lack of solar expertise available in the agencies.

Conclusions and Recommendations

Based upon the result of an analysis of Agencies' Ten Year Buildings Plans and supplemental data regarding solar energy and on a review of the activities of the "656" Committee regarding solar, the following conclusions are made:

- Agencies have installed solar heating, cooling and hot water systems in the past using their own funds and are planning to install additional systems between FY 1981 and FY 1985. The number of systems planned (125) is almost half of that undertaken in the past (206). Agencies will give preference to installation of solar systems in Federal bulldings, when life cycle cost effective. However, the life cycle costing criteria, particularly the discount rate, prevents much activity in this area. Due to the funding competition of solar applications with more cost-effective energy conservation 
opportunities, agencles are placing emphasis on conservation retrofit activities and operation and maintenance activities in meeting the $20 \%$ energy reduction goal of 1985.

- Agencies have participated on a cost-sharing basis with DOE for funding solar systems and are eager to obtain additional funds to install more solar systems. The agencies would like to undertake an additional 2737 systems if more dollars were available through SFBP. This total is twice as many as were undertaken in the past, and, if funded, could raise the total number of solar systerns in Federal buildings to 3880 or $0.6 \%$ of all Federal buildings.

- Agencies, especially regional office staff or building operators, need additional technical assistance for making informed decisions on installation of solar systems in Federal buildings.

Based on these conclusions, the following recommendations are made:

1. Provide agencies with additional technical assistance. This may be accomplished through small informal workshops held periodically at the field operating level for project development personnel and at agency request. These workshops would address specific technical questions or problems agency representatives many have in identifying the potential for solar in Federal buildings, installing solar systems, assessing the quality of solar equipment, and operating and malntaining the solar systems. This technical assistance should be provided to agencies regardless of their participation in the Solar Federal Buildings Program.

2. Extend the program funding until the total iffe cycle costs of solar systems appear to be more competitive with other energy conservation opportunities, or until the funding and management of solar systems design, acquisition, and installation is a standard part of agencies' construction programs. Most agencies are planning energy conservation retrofit activities other than solar to meet the energy reduction goal of 1985. At the same time, they would like to undertake additional solar projects but funding priority goes to those activities which minimize total life cycle costs, which in most cases are activities other than solar. Based on this, most agencies need additional funds to undertake solar systems. Extension of program funds would provide this opportunity to the agencies. Extension of the program would also enable DOE to ensure program continuity, specifically in terms of fulfilling their responsibility of directing, coordinating, and stimulating solar activities in Federal agencies. 


\section{INTRODUCTION}

The purpose of this report is to provide the Department of Energy's Solar Federal Buildings Program with data on the Federal agencies' activities and plans regarding the use of solar energy in their buildings, and consequently, to make recommendations concerning the Solar Federal Buildings Program's plans.

Specfically this report encompasses an analysis of agencies Ten Year Buildings construction, leasing and retrofit plans to provide visibility for and detailed knowledge of Federal agencies planning regarding solar and other renewable energy resources. This report, contains the results of the analysis conducted, pertinent statistical information regarding planned solar projects, and recommendations concerning the SFBP plans.

Data provided. in the report are derived from activities performed under DOE's Federal Energy. Management .Program (FEMP). The Federal Energy Management Program (FEMP) of the Departinent of Energy (DOE) is responsible for monitoring, coordinating, and reporting Federal Government activities in managing and controlling its use of energy. FEMP is divided into two broad program areas: (a) the Buildings Program, and (b) the General Operations Program. The primary emphașis of this report, is aimed at activities covered under the Buildings Program. The Buildings Program is intended to reduce the amount of energy consumed through increasing the efficiency of cooling, heating, lighting, and ventilation in Federal buildings. Additionally, the Federal Energy Management Program provides support to the "656" Committee in identifying actions to be undertaken by the inter-agency working groups. One of the areas addressed by the working groups is renewable energy resources utilization by Federal agencies. A summary of the activities undertaken by the "656" Comittee regarding the use of solar energy is also presented in this report.

The report is organized in the following manner: first, the background of the Ten Year Buildings Plan, Guidelines For Preparation of the Ten Year Buildings Plans, status of the Buildings Plans submissions, and the "656" Committee activities will be discussed. Second, the findings of the Ten Year. Buildings Plans and supplemental data, and findings of the "656" Committee regarding solar activities and plans of Federal agencies will be discussed. Finally, conclusions and recommendations will be made regarding SFBP plans.

This report is primarily based upon the available data obtained from each agency's Ten Year Buildings Plan. Close. scrutiny of the data reported to DOE by the various agencies has revealed that it is, on occasion, fragmented, contradictory and lacking in precision due to this being the first attempt in developing such a comprehensive plan. Greater specificity is required for valid and reliable buildings plans.

To the extent possible, data inconsistencies found in the plans were resolved through supplemental data and through telephone conversations. Supplemental solar data were requested of the SFBP participants by the DOE/Office of Solar Applications for Buildings. This supplemental data provided a means of validating data obtained: through the Plans and also provided additional data necessary for assessing agencies activities and plans for the use of solar in Federal buildings. 


\section{BACKGROUND}

\section{A. Guidelines For Preparation of Ten Year Buildings Plans}

In November 1979, the Department of Energy published "Gudelines for Ten Year Buildings Plans," incorporating the requirements from NECPA; EPCA and

Executive Order 12003. These Ten Year Buildings Plans are required of all Federal agencies owning and operating or leasing and controlling buildings. The Buildings Plans are prepared as part of an Overall Energy Management Plan required of each Federal agency. Information from the Buildings Plans will be incorporated into the President's Ten Year Plan for energy conservation in buildings. The plans were to be submitted to DOE for evaluation and approval by May 14, 1980 .

The guidelines specify the requirements for plan content and submission date. Also included in the guidelines are performance oriented goals and objectives that are to be adopted by the agencies and stated in their plans. The goals and objectives are established pursuant to Executive Order 11912 as amended by Executed Order 12003 and include:

- Achieve a 20 percent reduction in average energy use per gross square foot in 1985 as compared to the 1975 baseline energy use.

- Achieve a 45 percent reduction in the design energy use per gross square foot of new buildings in 1985 as compared to the 1975 baseline energy use of existing buildings.

- Set a goal for reducing energy use in leased buildings.

- Set a goal for instaliing renewable energy systems in existing and new Federal buildings.

- Achieve a 30 percent reduction in the use of petroleum based fuels in 1985 as compared to the use in 1975.

The Guidelines specified requirements for the following areas, which were addressed as separate sections in the guidelines:

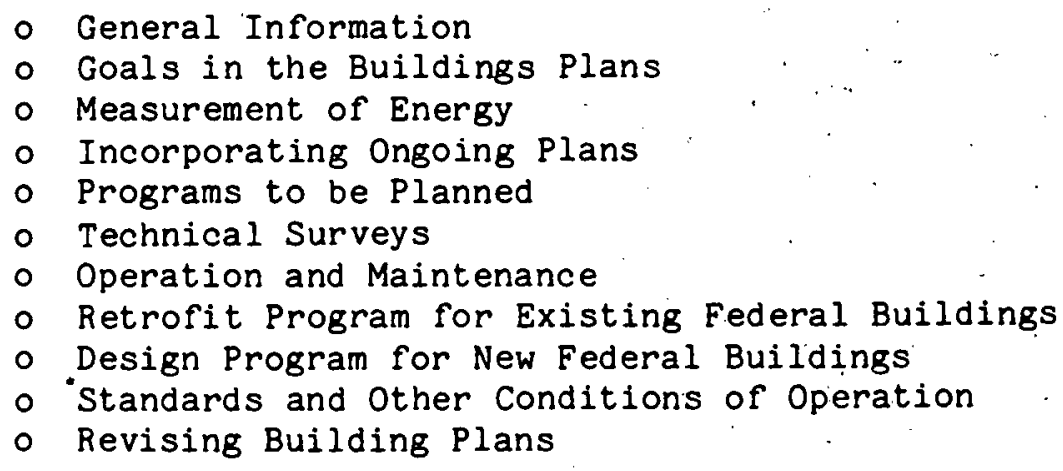

Five sections of the Guidelines specified requirements for inclusion of solar and renewable energy data in the buildings plans.

There are a total of sixty-nine Federal agencies. Twenty-four agencies own and operate or lease and control buildings and are therefore required to submit Buildings plans. Four of these agencies have been granted waivers by DOE for submitting plans. A total of seventeen plans have been received, to date. Below is a list of the agencies required to submit Buildings Plans. 
Astericks (*) Indicate the agency Plans that have not been received and "w" indicates a waiver was granted to that agency.

(1) Department of Agriculture

w (2) Commodities Futures Trading Commission

w (3) Community Services Administration

(4) Department of Commerce

(5) Department of Defense

(6) Department of Energy

(7) Environmental Protection Agency

* (8) Federal Communications Commission

w (9) Federal Home Loan Board

(10) General Services Administration

(11) Department of Health, Education, and Welfare

(12) Department of Interior

w (13) Interstate Commerce Commission

(14) Department of Justice

(15) National Aeronautics and Space Administration

(16) Department of Labor

* (17) National Science Foundation

(18) Panama Canal Company

(19) United States Postal Service

* (20) Department of State

(21) Tennessee Valley Authority

(22) Department of Transportation

(23) Department of Treasury

(24) Veteran's Administration

\section{B. Functions of the "656" Committee}

The Interagency Federal Energy Policy Committee, "656" Committee provides coordination of interdepartmental Federal Energy Management activities. The Committee is composed of designated senior level representatives of the following agencies: Department of Defense, Department of Commerce, Department of Housing and Urban Development, Department of Transportation, Department of Agriculture, Department of the Interior, United States Postal Service, General Services Administration, NASA, and the Veteran's Administration. The Chairman of the Committee is the Under Secretary of DOE and the Vice Chairman is the Administration of General Services.

The "656" Committee established six working groups to act as positive mechanisms for generating cooperative solutions to common energy management problems. Specifically, the six working groups would determine energy conserving actions that can be implemented quickly. The six groups are concerned with the following areas:

- Transportation

- Buildings

- Acquisition Policy

- Products

- People

- Data Gathering and Reporting 
Each senior level principal "656" Comititee member designated a member or members of his organization to participate in the working groups and Agencies not represented on the "656" Committee were invited to provide representatives to the Working Groups.

The Working Groups address probiems, concerns, and activities within the six energy management areas. Among these are concerns for the use of solar energy in Federal buildings, and activities that can be undertaken to promote a greater awareness of the potential of solar energy in Federal buildings. 


\section{DISCUSSION OF FINDINGS}

This Section presents the findings of the evaluation of (a) Federal Agency Ten Year Buildngs Plans, (b) Supplemental data requested of the Federal agencies by the DOE Office of Solar Applications for Buildings and (c) "656" Committee activities and concerns for the use of solar energy in Federal Buildings. As stated in the Preface of this report, the supplemental data were used to validate the data extracted from the Buildings Plans, as well as provide additional data for an assessment of agency activities and plans for solar.

\section{A: Evaluation of Ten Year Buildings Plans}

Five sections of the Guidelines for Building Plans specified requirements for inclusion of solar and renewable energy data. These sections are as follows:

Goals in the Buildings Plans

Incorporating Ongoing Plans

Programs to be Planned

Retrofit Program for Existing Federal Buildings

Design Program For New Federal Buildings
- Section 436.44

- Section 436.46

- Section 436.47

- Section 435.50

- Section 436.51

The specific solar requirements of each of these sections have been extracted from the Guidelines and are described in the subsections that follow. Agency compliance with these requirements and a discussion of the results will also be presented.

1. Goals in the Buildings Plans

a. Requirements (Section 436.44 )

(Paragraph a)) "The goals set under this section shall be stated in the Buildings Plans and are established pursuant to Executive Order 11912, as amended. Consistent with applicable requirements for life cycle cost analyses under Subpart A of this part, each Federal agency shall aim to achieve the goals (paragraph $f$ ) to the maximum extent practicable unless a waiver is granted."

(Paragraph f)). "For the purpose of promoting reduced dependence on scarce fossil fuels in planning to achieve overall building goals under this section, in a manner consistent with Subpart A of this Part, each Federal agency shall provide in its Buildings Plan goals for installing renewable energy systems in existing and new Federal buildings."

\section{b. Compliance with Requirements}

All agencies stated preference would be given to installation of solar systems when the systems are determined to be cost-effective, consistent with life cycle costing guidelines. Thus, all agencies have complied with paragraph (a) above. However, only seven agencies specifically stated a quantitative goal for the contribution of solar and renewable energy to the 1985, reduction goal. Three agencies expressed their goals in terms of installing solar systems in a percentage of buildings or gross square feet. Others expressed their goals in terms of deriving a percentage of their energy use from solar systems.

c. Discussion of Results 
As indicated above agencies established goals for installing solar and renewable energy systems. The agencies and their goals are as follows:

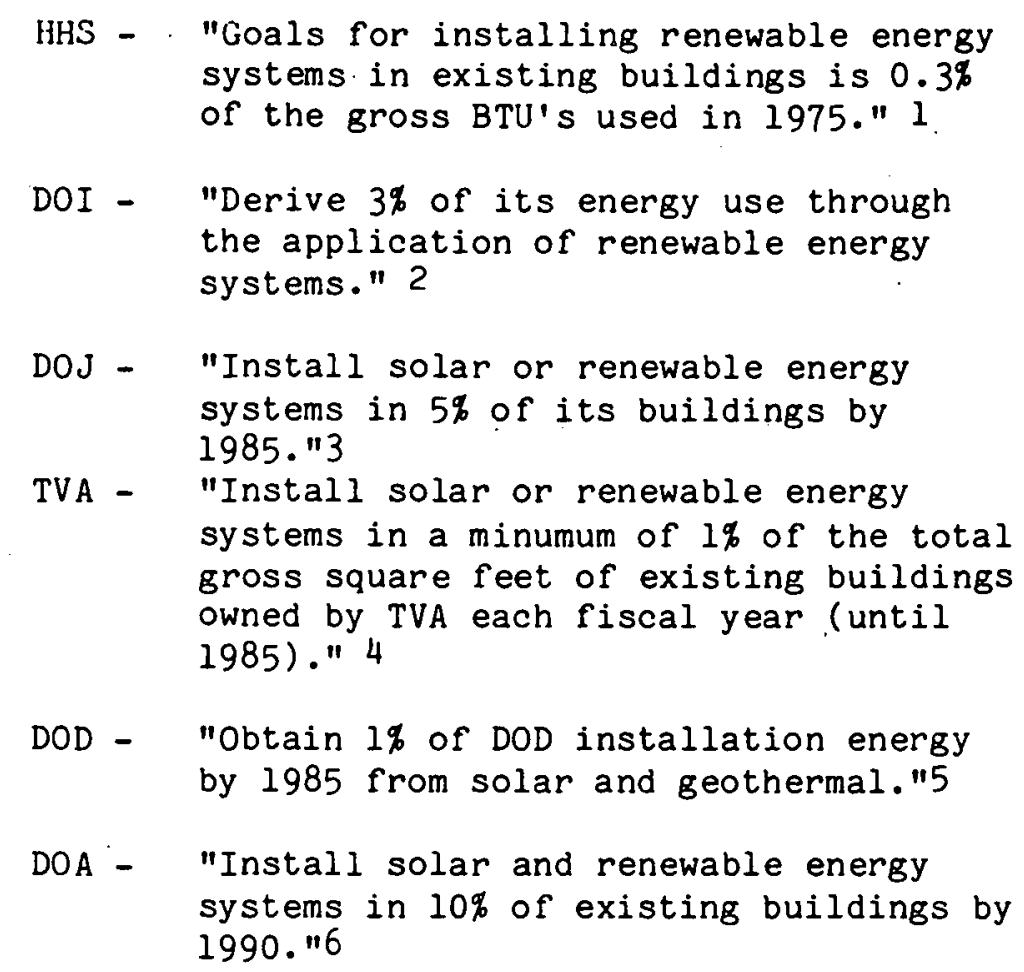

The requirements for establishing goals refer to solar and renewable energy systems. Therefore, it is not known what percentage of the goals refer to strictly solar heating, cooling and hot water systems. For example, DOI stated their goal would be achieved through installation of 192 solar and renewable systems at a cost of $\$ 8$ million. It is not known how many of the systems are solar heating and cooling. However, the Department of Health and Human Services specifically stated their goal would be achieved through installation of solar heating and cooling systems funded by DOE's Solar Federal Buildings Program

Those agencies which did not specify a goal for installing solar and renewable energy systems stated preference would be given to these systems when they are cost-effective (calculated in accordance with life cycle costing guideline). Many of the agencies said passive solar features would be included in new buildings designs and active solar features would be considered for all new buildings, if life cycle cost-effective.

\section{Incorporating Ongoing Plans}

a. Requirements (Section 436.46)

(Paragraph (a) "The Buildings Plans shall include information on existing Federal buildings which, as a result of energy-saving actions such as changes in operation and maintenance practices or installation of alternative building systems occurring between October 1, 1975, and September 30, 1980, have made progress toward the 20 percent goal set forth in Section 436.44 (paragraph $f$ ). 
(Paragraph (b)) "The information on existing Federal buildings under section 436.46 (a) shall include by fiscal year and category -

(1) The number and gross square footage of Federal buildings in which energy-saving actions occurred or are already budgeted to occur;

(2) A description of the energy-saving actions, particularly those involving renewable energy systems, which were taken or are budgeted to occur:

(3) Total energy-savings as expressed in.BTU's calculated in accordance with the section on measurement of energy;

(4) Energy-savings in average energy use, as expressed in BTU's per gross square foot of floor area calculated in accordance with the section on measurement of energy;

(5) Energy cost savings; and

(6) Cost of achieving savings."

b. Compliance with Requirements

In Paragraph (b) (2) above the agencies are required to discuss their energy-saving actions, particularly those involving renewable energy systems. All other solar data required for ongoing activities are aggregated with the data on other energy-saving actions: Therefore, agencies are not required to specify the dollars or savings specifically associated with the solar systems. However, some agencies did report this data: Also, the supplemental data requested from the agencies by the office of solar Applications for Buildings provided this information.

In summary, eleven of the seventeen agency plans that were submitted indicated ongoing activities regarding solar and renewable energy systems. More detailed information on these activities is provided in Table II-l.

\section{c. Discussion of Results}

Eleven of the seventeen agencies that discussed ongoing solar activities participated in the Department of Energy's Solar Heating and Cooling Demonstration Program. In addition, Agencies have funded installation of solar heating, cooling, and hot water systems on their own. initiative.

Two hundred and six projects have been undertaken solely by the agencies at a cost of $\$ 34.320$ million. The DOE has funded 59 solar systems for Federal build'ings through the DOE Solar Heating and Cooling Demonstration program at a cost of approximtely $\$ 7.8$ million. (See Table II-2 for projects funded under the Solar Heating and Cooling Demonstration Program).

The Department of Defense has funded the largest number of systems. Seventy systems are operational or have been funded for construction for the period 1975 thru 1980 at a cost of approximately $\$ 23$ million. According to the 
TABLE II-1

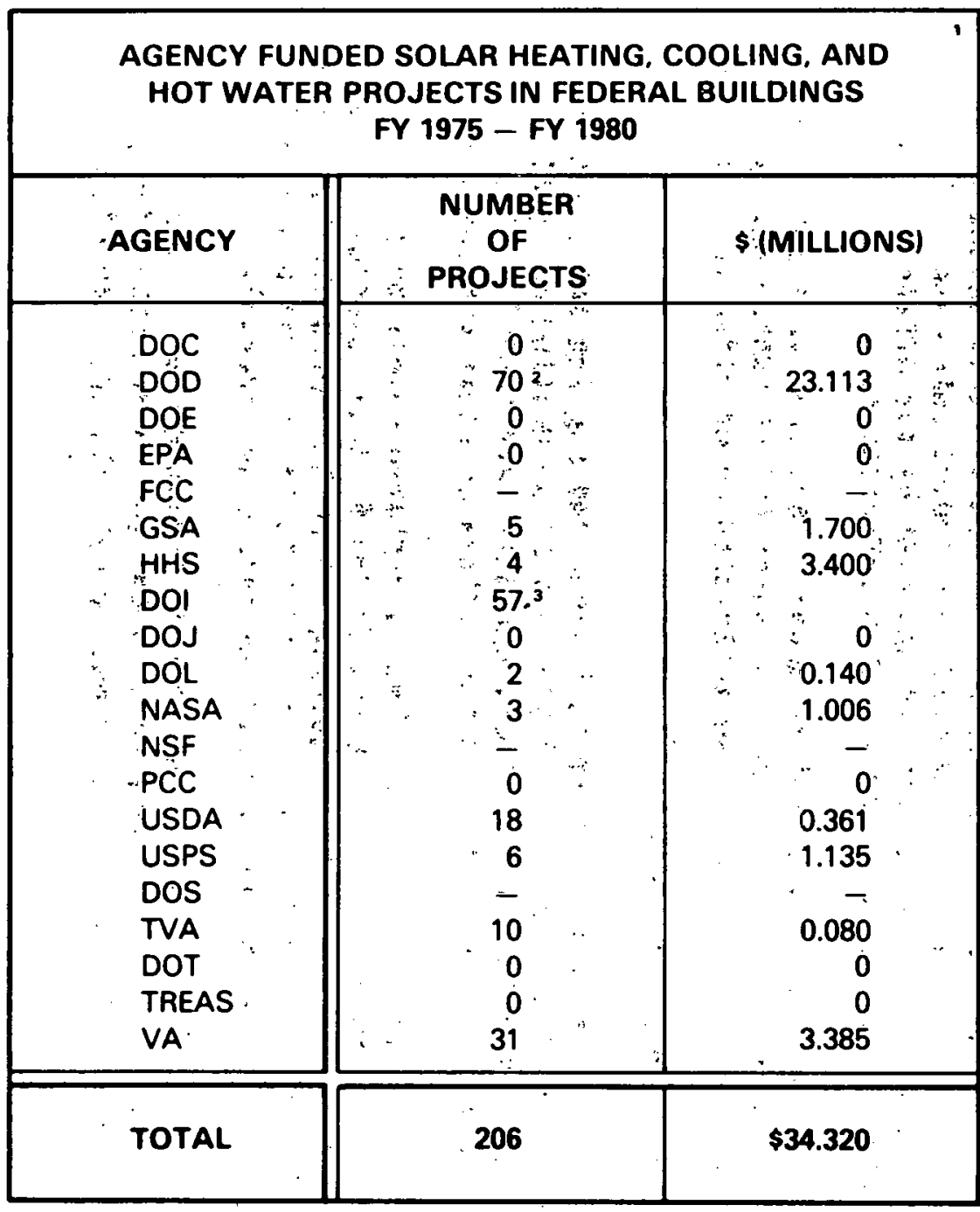

- Data was obtained from Ten Year Buildings Plans, supplemental data sources, or telephone conversation with agency representatives. Projects are operational or under construction.

2 Figures were extracted from "DOD Solar Energy Projects Summary Book", March 1980.

Expenditure for the 57 systems was not available
TABLE $\|-2$

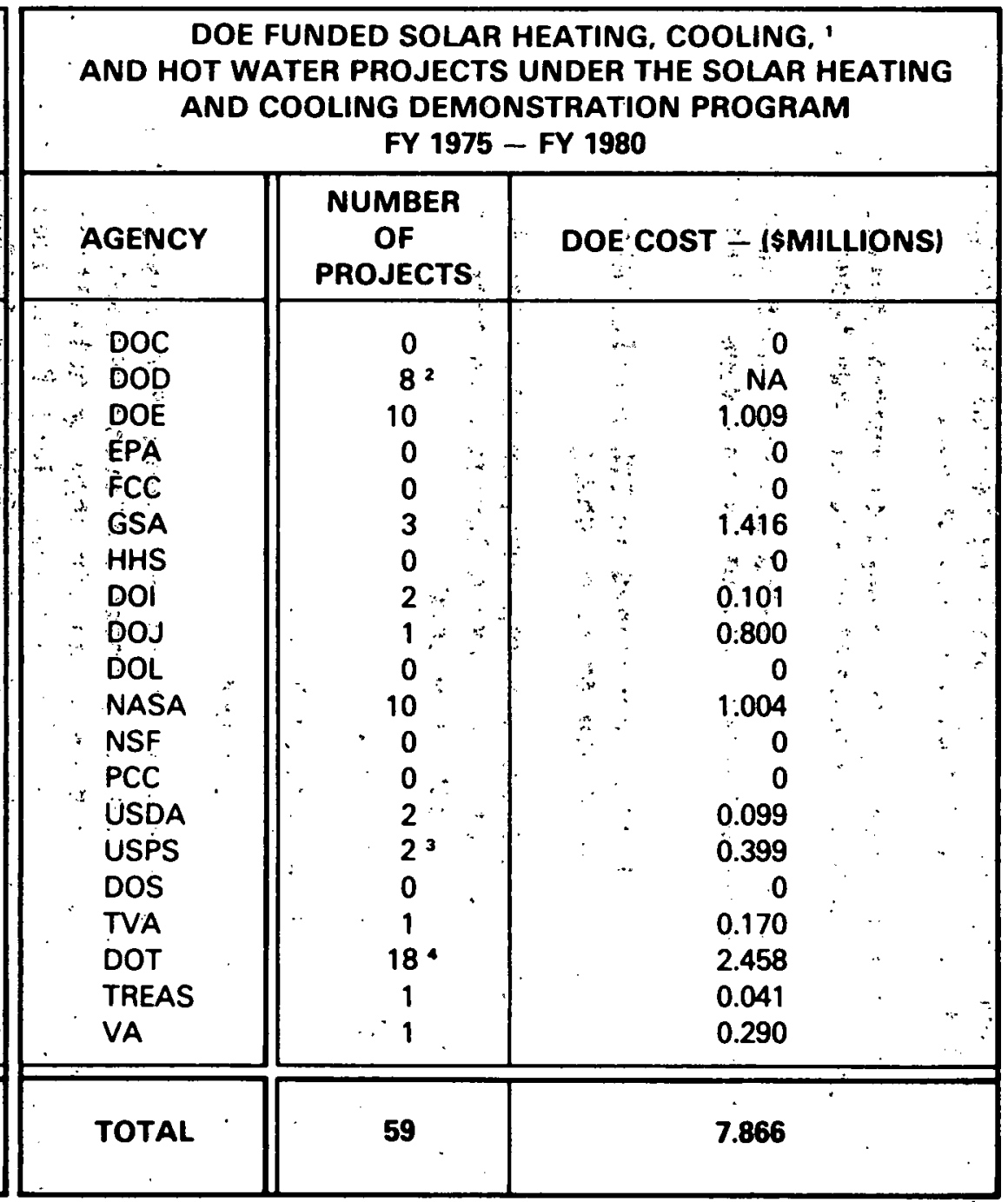

1 Data was obtained from DOE. Cost figures may not be current.

2 Total dollars for DOE were not available.

Reflects cost figures for only 1 project.

- Reflects DOE cost share for only 3 projects. 
Military Construction Authorization Act of 1980, DOD shall include in all construction contracts a requirement to furnish and install solar systems, if such systems can be shown to be cost effective.

All other agency investments total $\$ 11.207$ million. A total of 136 systems were funded by all agencies other than DOD. The DOI and the Veteran's Administration, respectively, have 57 and 31 solar systems operating or funded for construction.

The Veteran's Administration has invested approximately $\$ 3.385$ in these systems. DOI's investment could not be determined from their Buildings Plan.

\section{Programs to be Planned}

a. Requirements (Section 436.47 )

Paragraph (a)) "Each Buildings Plan to achieve the goals under section 436.44 shall be based on the maximum use of renewable energy systems consistent with these guidelines."

\section{b. Compliance with Requirement}

It is difficult to evaluate agency compliance with this requirement. All agencies reported solar and renewable energy systems would be used to the maximum extent in retrofit and leasing activities as well as new construction, when consistent with the life cycle costing guidelines.

\section{c. Discussion of Results}

As stated, all agencies indicated the maximum use of solar and renewable. energy systems would be undertaken, consistent with life cycle costing guidelines. However, some agencies indicated little contribution is expected from solar and renewable energy sources by 1985 , due to its unattractive life cycle costs. Statements made by some of the agencies that indicate their experience and attitude about the potential of solar energy in their buildings are as follows:

USPS - "Experience to date in the Postal Services Solar Demonstration Program continues to show that active solar systems are generally not life cycle cost-effective". ..."At this time, solar demonstration projects with active heating and cooling solar systems are not life cycle cost-effective, primarily because of the high initial cost of the systems"....

"Consideration of any additional active systems other than domestic hot water. will be held in abeyance pending. evaluation of all demonstration projects. To date, active heating and cooling solar.systems have not been shown to be cost-effective. However, 
it is felt that small and medium size post offices, particularly those under 30,000 square feet are prime candidates for passive solar designs, either partial or total."7

DOE- "Little contribution from renewable energy sources is expected by 1985."8

GSA- "The potential for renewable energy applications is limited by the current life cycle cost methodology which uses a 10 percent discount factor and the funding competition of these applications with more cost-effective energy conservation projects."

"Future infliatives in the application of active solar energy systems to existing buildings is severely limited by their unattractive life cycle cost benefits." 9

At the time of the requirement for submission of the Buildings Plans the life cycle costing guidelines required the use of $10 \%$ discount rate. According to the Energy Security Act of 1980 , the discount rate has been decreased to $7 \%$ for calculating the life cycle costs of conservation and solar investments in Federal buildings. The impact of this requirement on the cost-effectiveness of the agencies plans for solar investments is not yet known.

\section{Retrofit Program For Existing Federal Buildings}

a. Requirements (Section 46.50)

(Paragraph (a)) Consistent with Section 436.48 and Section $436.49(\mathrm{c})$ and on the basis of preliminary energy audit data and technical surveys, each Federal agency shall provide in its Buildings Plan for progress toward achievement of the goals for existing Federal buildings under Section 436.44 by retrofitting its existing Federal buildings with alternative building systems which are life cycle cost effective to the Federal agency, as measured by a savings to investment ratio calculated under Subpart $A$ of this Part, and which are selected in accordance with this section."

(Paragraph (b)) In planning for the retrofit of existing Federal buildings with life cycle cost-effective alternative bullding systems; each Federal agency shall provide in its Building Plan to assign highest priority to those existing Federal builidings in which installation of alternative building systems is likely to be most life cycle cost-effective."

(Pararaph (d)) With respect to alternative building systems which use renewable energy sources, the Buildings Plans shall - 
(1) State the number and gross square footage of Federal buildings to be retrofitted;

(2) Describe the type of renewable energy systems to be used;

(3) State the estimated or actual cost savings; and

(4) State the estimated or actual cost of achieving estimated energy savings and cost savings."

b. Compliance with Requirements

All agencies stated solar and other renewable energy sources would be used to reduce energy consumption when the renewable sources are determined to be cost-effective. However, only two agencies complied totally with the requirements of this section. Inconsistencies in data reported under Paragraph d were resolved through telephone conversations or comparison with supplemental data. Most agencies discussed the number of systems to be installed and an approximation of the investment cost. On occasion, a breakout of the type of system was given. See Table II-3 for an account of the agencies solar heating and cooling retrofit activities planned for FY 1981 thru FY 1985.

\section{c. Discussion of Results}

According to the agencles Buildings Plans, a total of 125 solar systems at a cost of $\$ 45.590$ million are planned for FY 1981 - FY 1985. In addition to these planned systems are 842 recently awarded solar projects through the Solar Federal Buildings Program. The systems to be funded through the SFBP are expected to be operational between FY 81 and FY 85 . The Department of Defense appears to be planning the largest number of solar heating, cooling, and hot water systems. Eighty-four systems at an estimated cost of $\$ 40$ million are in the design stage, and if proven to be cost-effective, they are expected to be constructed and operational by 1985. The Department of Interior has plans to install 85 solar and renewable energy systems at a cost of $\$ 4.8$ million. However, the exact number of solar heating, cooling, and hot water systems was not. specified in the plans. Twenty solar hot water systems are planned by the Veteran's Administration at a cost of $\$ 3$ million. The retrofit solar plans of DOD and the Veterans Administration represents $96 \%$ of all planned solar projects discussed by the agencies in their Buildings Plans (excluding DOE/SFBP funded projects).

Three other agencies also stated plans for. installation of solar systems. DOC is planning to install three solar hot water systems at a cost of $\$ 15,000$. USPS is considering installation of three systems, and TVA has requested funds in 1981 for the study, design, and installation of twelve solar systens.

In addition to the above planned projects, the agencies discussed in their Bulldings Plans solar projects recently awarded by DOE/SFBP. Fifteen of the agencies that are to submit plans have recently been awarded funds from DOE to install 842 solar systems. (Table II- 4 presents a distribution of the solar projects recently awarded by SFBP.) The Department of Treasury, Department of Commerce, Department of 


\begin{tabular}{|c|c|c|}
\hline \multicolumn{3}{|c|}{$\begin{array}{l}\text { TABLE II-3 FEDERAL AGENCIES' PLANS FOR SOLAR HEATING, COOLING, AND ' } \\
\text { HOT WATER SYSTEMS } \\
\text { FY } 1981-1985\end{array}$} \\
\hline AGENCY & NUMBER OF PROJECTS & (\$ MILLIONS) \\
\hline $\begin{array}{l}\text { DOC } \\
\text { DOD } \\
\text { DOE } \\
\text { EPA } \\
\text { FCC } \\
\text { GSA } \\
\text { HHS } \\
\text { DOI } \\
\text { DOJ } \\
\text { DOL } \\
\text { NASA } \\
\text { NSF } \\
\text { PCC } \\
\text { USDA } \\
\text { USPS } \\
\text { DOS } \\
\text { TVA } \\
\text { DOT } \\
\text { TREAS } \\
\text { VA }\end{array}$ & $\begin{array}{r}6 \\
12 \\
20\end{array}$ & $\begin{array}{l}2.045 \\
0.450 \\
3.080\end{array}$ \\
\hline TOTAL & 125 & 45.590 \\
\hline
\end{tabular}

- Data is obtained from Federal agencies' Ten Year Buildings Plan.

2 DOD data was obtained from "DOD Solar Energy Project Summary Book", March 1980. Total represents oystems under design.

2 DOI indicated in their Plan 85 solar and renewable energy systems at a cost of $\$ 3.313$ million are planned for FY 81-85. The number of solar heating and cooling systems included in these figures are not known. 


\begin{tabular}{|l||r|r|}
\hline \multicolumn{2}{|c|}{ TABLE II-4 DOE SOLAR FEDERAL BUILDINGS PROGRAM PROJECTS } \\
(FUNDS OBLIGATED IN FY 1980) \\
\hline AGENCY & NUMBER OF PROJECTS AWARDED & \$ (MILLIONS) AWARDED \\
\hline DOC & 6 & 0.86 \\
DOD & 41 & 6.64 \\
DOE & 18 & 4.08 \\
EPA & 1 & 0.18 \\
FEMA & 1 & 0.03 \\
GSA & 123 & 4.00 \\
HHS & 9 & 2.64 \\
DOI & 551 & 3.18 \\
DOJ & 14 & 1.77 \\
DOL & 10 & 1.75 \\
NASA & 10 & 1.77 \\
TVA & 11 & 0.14 \\
DOT & 7 & 0.95 \\
TREAS & 29 & 0.86 \\
USDA & 6 & 1.18 \\
VA & 6 & 1.11 \\
\hline
\end{tabular}


Transportation, and Department of Justice indicated they are eager to receive funds from DOE for installing additional solar and renewable energy systems.

USPS, HHS, and GSA, as indicated in Section II.A.2.c, feel that the potential for solar and renewable energy systems is limited because of its unattractive life cycle cost. Few solar systems were planned by these agencies. GSA stated, "projections of the number of buildings to be retrofitted are difficult to make at this time, but will be made in the future." GSA also said, "the potential for renewable energy applications is limited by the life cycle costing methodology which uses a 10 percent discount rate and the funding competition of these applications with more cost-effective energy conservation projects." HHS and USPS expressed similar feelings. HHS plans on achieving their $0.3 \%$ goal through the projects funded by SFBP, but their experience with solar systems has been that they are not cost-effective on a life cycle cost basis. USPS said "no further demonstrations of active solar heating and cooling systems are currently planned, but, additional passive systems will be considered as part of the normal design process. Consideration of active systems is held in abeyance pending evaluation of all demonstration projects." USPS plans six systems, all passive, in new buildings. The U.S. Coast Guard, a division within the Department of Transportation, has identified 60 solar energy retrofit projects for various units. The total estimated cost of these projects is $\$ 2.3$ million. DOT did not give any indication of how, when, or if these projects were to be funded or installed.

Although agencies are planning installations of solar heating, cooling, and hot water systems, it appears from the buildings plans that the agencies plan to achieve the $20 \%$ reduction goal for existing buildings largely through operation and maintenance and conservation retrofit activities (other than solar). A few agencies indicated additional solar systems could be planned after a more thorough investigation is conducted to identify the potential of solar. The Department of Commerce, Department of Transportation, and Department of Agriculture and USPS have conducted preliminary solar assessments but they have indicated that further detailed investigations are needed to indicate the true solar potential. Currently, all agencies are required to conduct technical surveys on their existing buildings. These surveys will identify any additional potential of solar for buildings. All surveys are to be completed no later than June 30,1984 (See Appendix A 436.48(f), "Guidelines For Buildings Plans," Nov. 14, 1979 - Final Rule).

\section{Design Program For New Federal Buildings}

\section{a. Requirements (Section 436.51 )}

(Paragraph (c)) "Each Federal agnency shall plan to install one or more active or passive solar, or other renewable energy system, to provide energy for bullding energy use unless the Federal agency states in the annual report under Section 436.56 that such a system would not minimize total life cycle costs as calculated under subpart $A$ of this part." 
(Paragraph (-d)) "Distinguishing between owned and leased new Federal buildings to be designed, the Buildings Plan stiall provide by fiscal year, to and including FY 1985, -

(1) Estimated amounts of construction, by number of buildings and gross square feet, for each category of new Federal buildings:

(2) Estimated average annual energy use per gross square foot for each category of new Federal buildings;

(3) The percentage reduction in estimated average annual energy use per gross square foot from the average annual energy use in FY 1975 as calculated under Section 436.44 ; and

(4) Estimated additional construction costs attributable to the alternative building systems incorporated in the designs of new Federal buildings in order to achieve the 45 percent reduction goal, and estimates of related cost savings."

b. Compliance with Requirements,

In accordance with paragraph (c), all agencies that submitted plans said at least one active or passive solar system would be installed in new buildings, unless it did not minimize total. life cycle costs. Thus, all agencies complied with this requirement.

According to the requirements of paragraph (d), agencies were to report aggregate data regarding new building construction and energy use, an estimate of percentage of reduction, and an estimate of additional costs attributable to alternative building systems. Under this requirement, (4) is the only element that requires data on solar and renewable energy projects. In their Building Plans, agencies discussed plans for installation of solar and renewable energy systems; however, none of the agencies gave an estimate of the construction costs associated with these plans. Thus, all agencies complied with paragraph (c) whereas, no agencies reporting plans for solar and renewable energy in new buildings complied with paragraph (d) 4.

\section{c. Discussion of Results}

All agencies will install at least one active or passive solar or other renewable energy system when such system(s) minimize total life cycle costs. Some agencies stated more than one system would be installed in new buildings. Also, most of the agencies stated alternative energy. sources such as active or passive solar systems will be more cost-effective for new Federal buildings as opposed to existing buildings. The DOI and USPS stated they plan installation of more than one active or passive system in new buildings, by 1985. DOI expects to utilize solar heating systems in four new buildings. The USPS stated "small and medium-sized post offices particularly those under 30,000 $\mathrm{gsf}$ are prime candidates for passive solar designs, either total or partial. At least one total or partial passive design will be initiated in each of the five postal regions." USPS established a goal of at least one new passive solar design per region for each succeeding year. HhS is planning installation of two solar systems in new hospitals and is requesting funds from DOE to supplement funding of these two systems. 
The USDA stated that no less than 25 percent of future new construction will incorporate renewable systems. They further stated "installation as a part of new construction is clearly the most effective from both a cost and practical stand point, and this is where the Department is placing its greatest emphasis." 14

Six of the seventeen agencies specified plans for new construction. An estimated total of 1,548 new buildings of about $28,944,160$ gross square feet are expected to be constructed by 1985. All but one agency provided an estimate of the gross square feet to be added to the existing inventory. The total gross square feet to be added, excludes estimates for five DOC Bulldings. A summary of the agencles plans for new buildings is found in Table II-5.

B. Summary of Supplemental Solar Data

On July 15, 1980, a letter was sent by DOE's Office of Solar Applications to the sixteen Federal agencies that are participating in the Solar Federal Buildings Program. These agencies were requested to review and update solar hardware expenditures (excluding DOE funded projects) for FY 79,80 and 81 , and also indicate the numbers of projects operating or funded for construction as of July 1980. These data were originally obtained six months ago and was used to supplement solar data obtained from the Domestic Policy Review (1978). The data was used to validate the data being obtained from the Buildings Plans.

In addition to the budget and project data that was requested, the agencies were asked to provide an estimate of the number of projects they would like to undertake, if additional dollars were available through the SFBP. These data are expected to support the SFBP request for additional funds. Table II- 6 provides a summary of the agencies responses.

Responses to the request indicate that the agencies wish to undertake additional solar projects. A total of 2,737 projects were reported as an. estimate of the number of projects that could be proposed if additional dollars were available. The projects are estimated to cost about $\$ 143$ million.

\section{Review of "656" Committee Activities Regarding Solar}

The Buildings Working Group is the only Working Group that has addressed the subject of solar energy. At a meeting held on June 2, 1980, a suggestion was made that the Buildings Working Group discuss taking a position on advocating the use of solar energy for buildings applications. There were many negative reactions to the suggestion from the group.

The recurring theme of the reactions were the following:

- Solar will never be life cycle cost effective at the present discount rate;

o. The solar technology is premature and should not be pushed; and

- There is little technical solar expertise available in the agencles for making judgements on installing solar systems. 
TABLE $\| 1.5$

\begin{tabular}{|c|c|c|c|c|}
\hline \multicolumn{5}{|c|}{$\begin{array}{l}\text { AGENCY OWNED EXISTING BUILDING INVENTORY AND NEW BUILDINGS PLANS } \\
\text { FY } 1981-\text { FY } 1985\end{array}$} \\
\hline AGENCY & $\begin{array}{c}\text { TOTAL NO. OF } \\
\text { OWNED } \\
\text { BUILDINGS } \\
\end{array}$ & $\begin{array}{c}\text { TOTAL GSF OF } \\
\text { OWNED } \\
\text { BUILDINGS }\end{array}$ & $\begin{array}{l}\text { ESTIMATE OF }{ }^{2} \\
\text { NO. OF } \\
\text { NEW BUILDINGS } \\
\end{array}$ & $\begin{array}{c}\text { ESTIMATE OF }{ }^{2} \\
\text { GSF OF } \\
\text { NEW BUILDINGS }\end{array}$ \\
\hline $\begin{array}{l}\text { DOC } \\
\text { DOD } \\
\text { DOE } \\
\text { EPA } \\
\text { FCC } \\
\text { GSA } \\
\text { HHS } \\
\text { DOI } \\
\text { DOJ } \\
\text { DOL } \\
\text { NASA } \\
\text { NSF } \\
\text { PCC } \\
\text { USDA } \\
\text { USPS } \\
\text { DOS } \\
\text { TVA } \\
\text { DOT } \\
\text { TREAS } \\
\text { VA }\end{array}$ & $\begin{array}{c}1,239 \\
403,721 \\
4,770 \\
91 \\
- \\
10,763 \\
2,410 \\
24,000 \\
1,879 \\
1,383 \\
2,429 \\
- \\
1,856 \\
177,846 \\
25,302 \\
- \\
593 \\
13,962 \\
281 \\
5,468\end{array}$ & $\begin{array}{r}6,734,079 \\
2,211,838,000 \\
93,289,960 \\
1,808,000 \\
- \\
330,000,000 \\
27,766,202 \\
55,063,318 \\
15,796,835 \\
9,008,807 \\
32,571,723 \\
- \\
8.909,117 \\
23,381,235 \\
178,749,000 \\
- \\
6,866,200 \\
43,863,935 \\
4,866,200 \\
111,660,000\end{array}$ & $\begin{array}{r}271 \\
566 \\
18\end{array}$ & $\begin{array}{c}3,136,000 \\
4,200,000 \\
1,464,490 \\
\cdot \\
19,840,000 \\
303,670\end{array}$ \\
\hline TOTAL & 524,525 & $3,166,810,374$ & 1,548 & $28,944,160$ \\
\hline
\end{tabular}

- Number of buildings and gross square feet of existing owned buildings is based on 1979 data.

2 Data based on agency building plans 
TABLE II-6

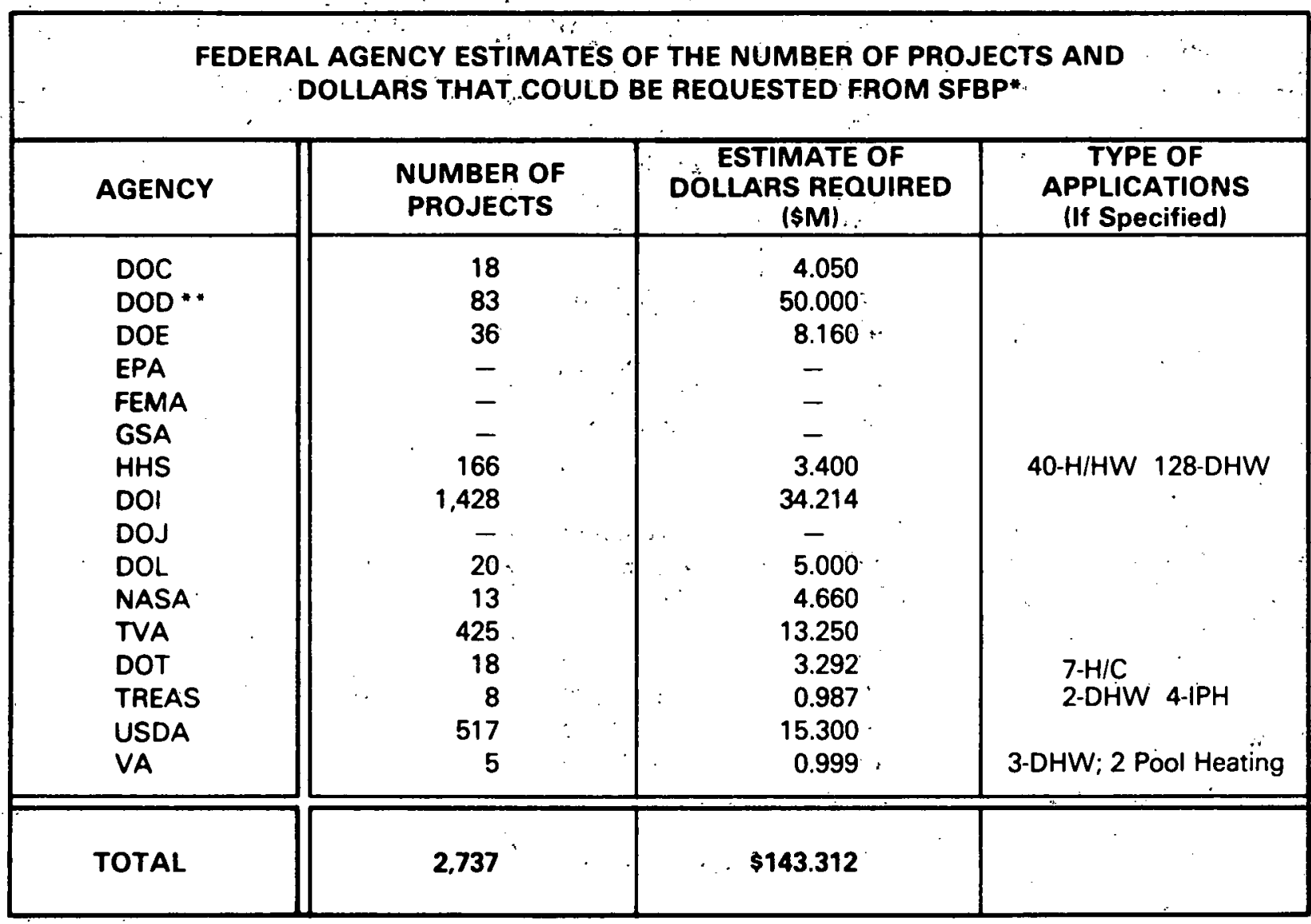

* Based on responses received to letter of July 15, 1980 from DOE's Office of Solar Applications to SFBP participants.

** No response from Army - Air Force Exchange Service and Navy. 
In response to the negative reactions of the group, the Chairman suggested a representative from the office of Solar Applications for Buildings be requested to address the group about the potential of solar for Federal buildings.

As yet, a date has not been set for the DOE Solar Applications representative to address the group. 
III. CONCLUSIONS AND RECOMMENDATIONS

An evaluation of the Federal agencies Ten Year Bulldings Plans, regarding solar energy, and a review of the "656" Committee Activities regarding solar energy, shows:

During FY 1975 - FY 1980, agencies invested $\$ 34$ million of their own funds for installation of 206 solar heating, cooling, and hot water systems; however, agencies are planning to install only an additional 125 solar systems during FY 1981 - 1985. DOD comprises the majority of these, with 84 systems planned, therefore, the residual 41 systems are planned by all other agencies. See Figure III-1 for graphical presentation of projects undertaken and funds expended for FY 1975 - FY 1980, and agencies plans for FY 1981 - FY 1985.

Agencies will give preference to solar systems for existing and new Federal buildings, when life cycle cost-effective (computed in accordance with life cycle costing guidelines). However, several agencies indicated that with respect to retrofitting existing buildings, the life cycle costing guidelines (the $10 \%$ discount rate, specifically) prevent much activity in this area. Also, due to the funding competition of solar applications with other more cost-effective energy conservation opportunities, agencies are placing additional emphasis on conservation retrofit activities and operation and malntenance activities in meeting the $20 \%$ energy reduction goal of 1985 . Agencies' comments on life cycle costing problems are based upon their use of a $10 \%$ discount rate. The change in the $10 \%$ discount rate to $7 \%$ will not become effective for use in life cycle costing until FY 1981, and therefore will not affect agency plans unt1l FY 1983, due to the timing of the submissions of FY 1982 budget requests.

Agencies are interested in obtaining funds from the Department of Energy to install additional solar heating, cooling, and hot water systems. Most agencies are already participating in DOE's Solar Heating and Cooling Demonstration Program and the Solar Federal Buildings Program. Additional evidence of the agencles' eagerness to obtain funds from DOE to install more solar systems is seen in the agencles responses to the DOE letter requesting estimates of the number of projects that could be submitted to DOE/SFBP if additional funds were available. The agencies responded with an estimate of 2,737 systems at an estimated cost of $\$ 143$ million. To date, under SFBP, sixteen agencies have been awarded funds for 84 projects at a cost of $\$ 31.14$ million. Therefore, agencles are indicating they would like to undertake three times as many projects as under the first cycle of awards. Figure III-2 presents graphically the DOE/SFBP funds obligated to each agency in FY 1980 and the estimates of the additional projects that could be proposed if dollars were available. Comparing Figure III-2 with Figure III-1, it is evident agencies are not planning many projects, but, at the same time are indicating they would like to receive DOE funds for additional projects.

Overall, there are approximately 1233 existing and planned solar projects in Federal buildings, including 206 agency funded, 59 Solar Heating and Cooling Program Demonstration funded, 125 agency planned, and 843 SFBP projects. Comparing this with the additional estimates of 2,737 systems desired, it appears agencies could undertake about twice as many projects as they have in the past. The total 3880 systems that could be undertaken could affect, at a minimum, $0.6 \%$ of the total number of Federal bulldings (assuming at least one bullding would be affected by each solar system). 


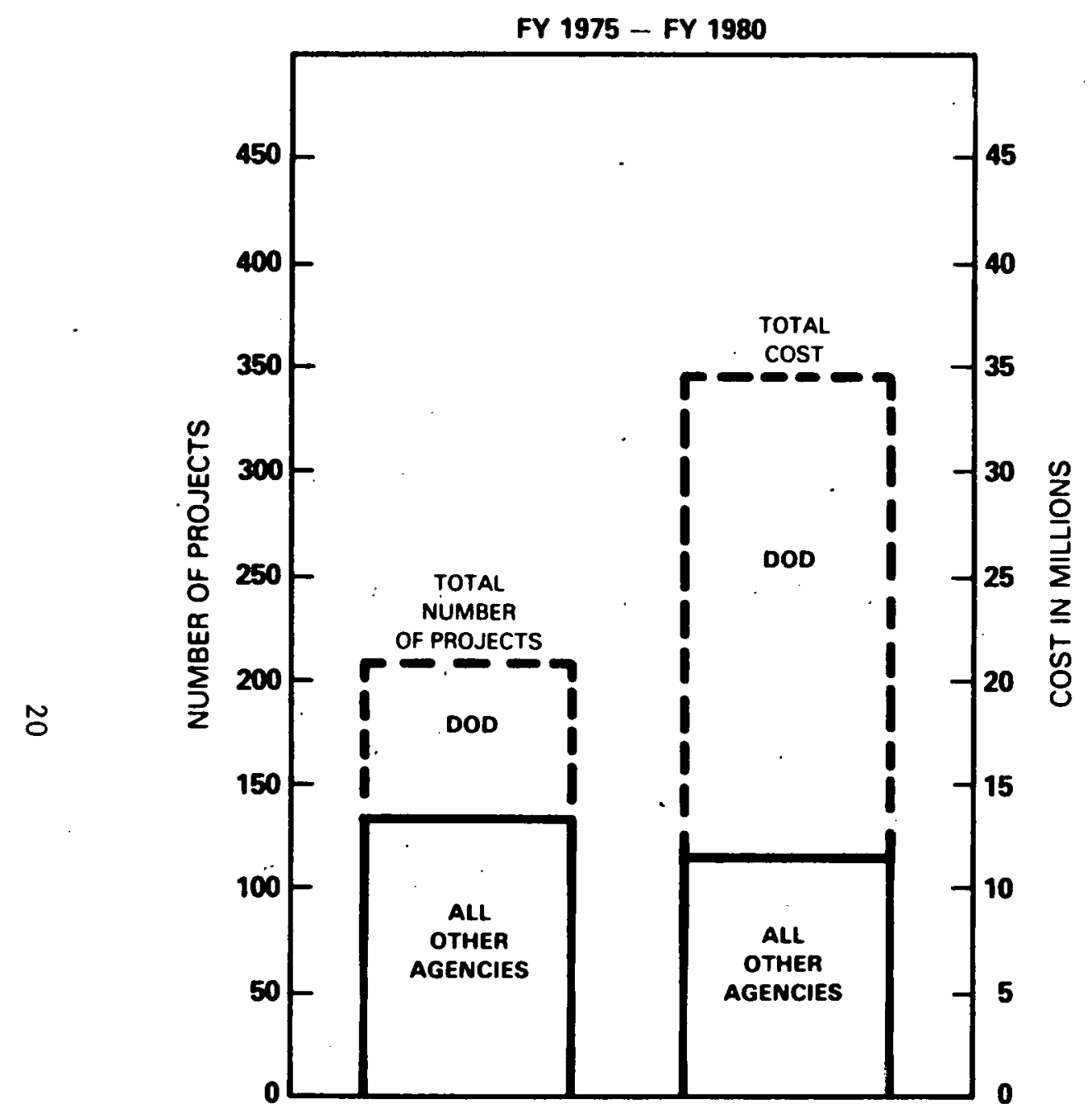

AGENCY FUNDED SOLAR HEATING, COOLING, AND HOT WATER PROJECTS

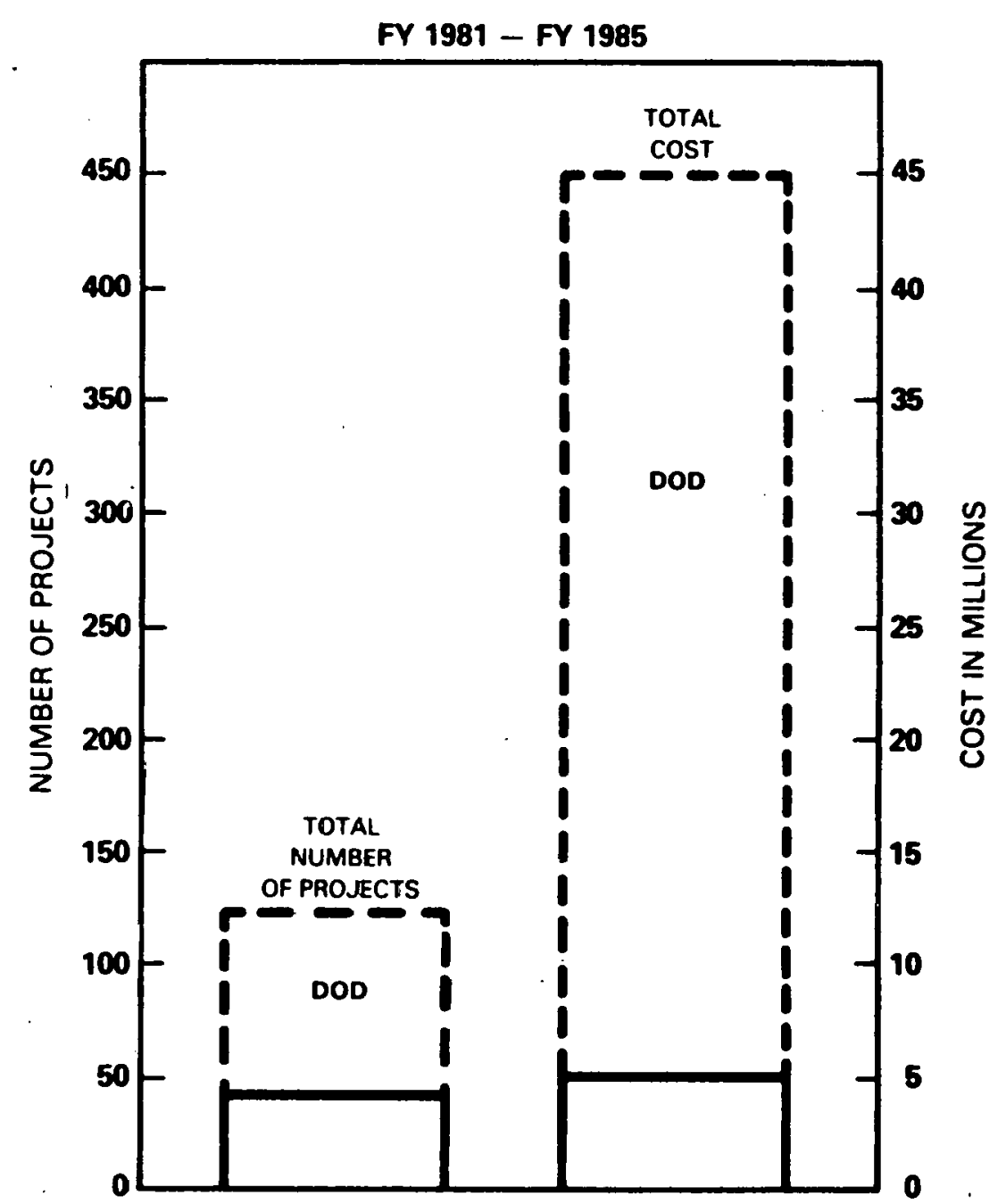

AGENCY PLANS FOR SOLAR HEATING, COOLING, AND HOT WATER PROJECTS

(Operational or Funded for Construction as of FY 1980) 


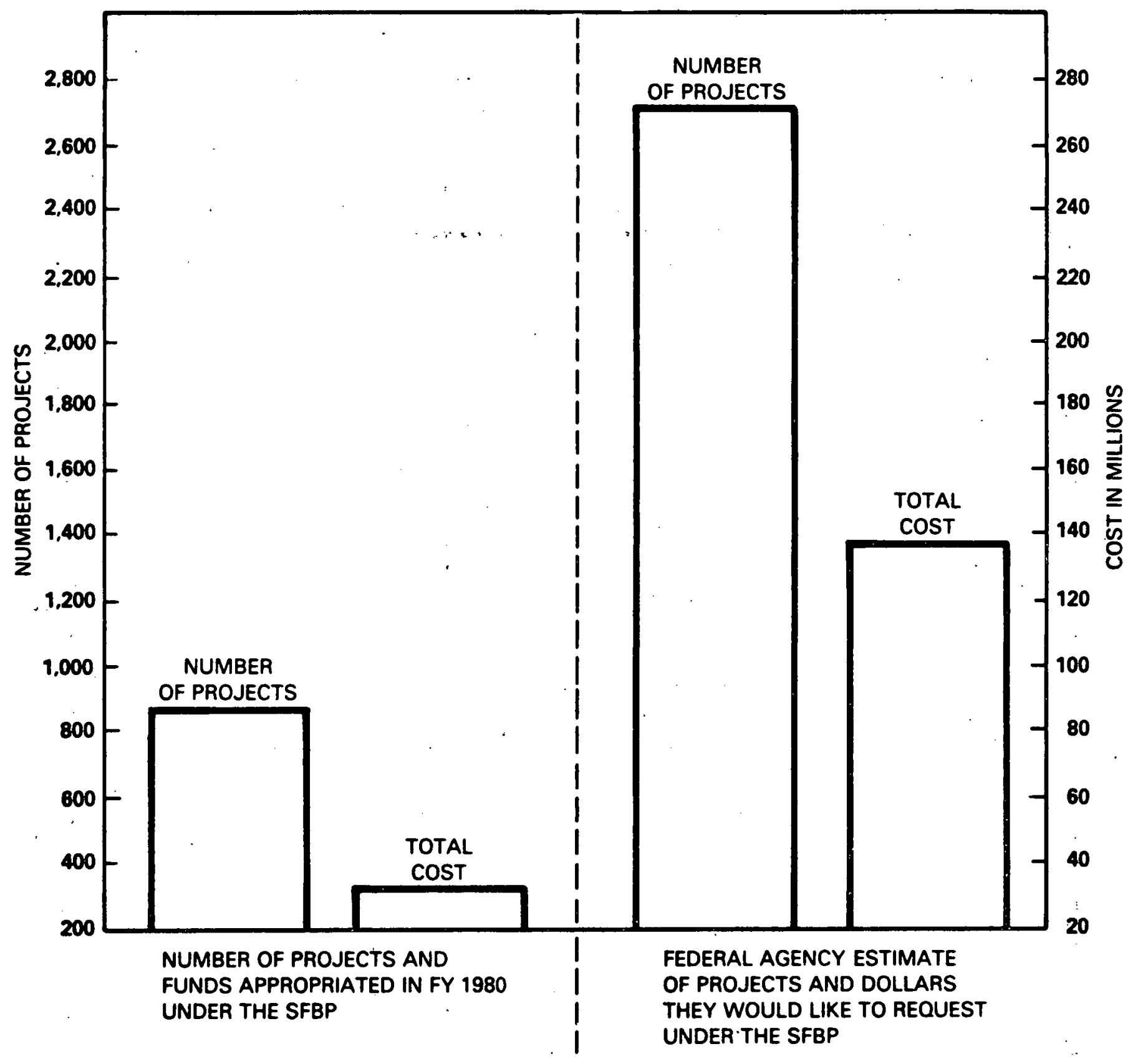

FIGURE III.2

COMPARISON OF FUNDS APPROPRIATED IN FY 1980 UNDER THE SFBP VERSUS AGENCIES ESTIMATES OF ADDITIONAL DOLLARS AND PROJECTS THAT COULD BE REQUESTED UNDER SFBP 
Agencies need additional technical assistance in making decisions about the use of solar heating and cooling in their bulldings. There is a lack of solar engineering expertise in agencies, especially at the field office levels. Agencies feel the lack of technical knowledge inhibits them from making informed decisions on installing solar systems. In many cases, the regional office staff or the individual building operators are the individuals who make decisions on buildings activities.

\section{Recommendations}

The following recommendations are based on the results of and the conclusions drawn from this report.

1. Continue to provide agencies with additional technical assistance. This may be accomplished through small informal workshops held periodically at the field operating level for project development personnel, and at agency request. These workshops would address specific technical questions or problems agency representatives may have in identifying the potential for solar in Federal buildings, installing solar systems, assessing the quality of solar equipment, and operating and maintaining the solar systems. This technical assistance should be provided to agencies regardless of their participation in the Solar Federal Buildings Program.

2. Extend the program funding capability to such time when the total ife cycle costs of solar systems appear to be more competitive with other energy conservation opportunities, or until the funding and management of solar systems design, acquisition, and installation is a standard part of agencies' construction programs. Most agencies are planning energy conservation retrofit activities other than solar to meet the energy reduction goal of 1985. At the same time, they would like to undertake additional solar systems but funding priority goes to those activities which minimize total life cycle costs, which in most cases are activities other than solar. Based on this, most agencies need additional funds to undertake solar systems. Extension of program funds would provide this opportunity to the agencies. Extension of the program would also enable DOE to ensure program continuity for the agencies and would also enable DOE to fulfill their responsibility of directing, coordinating, and stimulating solar activities in Federal agencies. 
FOOTNOTES

I Department of Health and Human Services, "Ten Year Buildings Energy Conservation Plan", pe

2 Department of Interior, "Ten Year Buildings Plan", p. 14

3 Department of Justice, "Ten Year Energy Conservation Plan for buildings", May, 1980, p. 3.

4 Tennessee Valley Authority, "Ten Year Plan for Reduction of Building Energy Use", p. 5.

5 Department of Defense, "Ten Year Buildings Plan", June 3, 1980, p. 14.

6 Department of Agriculture, "Ten Year Buildings Plan, p. 6.

7 United States Postal Service, "Energy Management Program, Ten Year Buildings Plan, May 1980 p..VI-3-4.

8 Department of Energy, "Ten Year Buildings Plan for Energy Conservation, May 1980, p. 29.

9 General Services Administration, "Ten Year Buildings Plan for Energy Conservation, $\mathrm{p}-6,25-26,39$.

10 Department of Health and Human Services, "Ten Year Energy Conservation Plan", p: 18.

11 General Services Administration, "Ten Year Buildings Plan for Energy Conservation" p. 24.

12 United States Postal Service, "Energy Management Program, Ten Year Buildings Plan," May. 1 1980, p. VI -4,

13 IBID, p. IX -13

14 Department of Agriculture, "Ten Year Buildings Plan," p. 6. 


\section{BIBLIOGRAPHY}

Department of Agriculture, "Ten Year Buildings Plan". August 28, 1980.

Department of Commerce, "Ten Year Energy Plan". July 3, 1980.

Department of Defense, "Ten Year Bulldings Plan". June 3, 1980.

Department of Energy, "Ten Year Bulldings Plan for Energy Conservation". May, 1980.

Environmental Protection Agency. "Energy Management Plan: Bulldings Plans". May 1980.

General Services Adminuistration. "Ten Year Buildings Plan for Energy Conservation". June 13, 1980.

Department of Health and Human Services, "Ten Year Energy Conservation Plan". June 3, 1980.

Department of Interior, "Ten Year Energy Conservation Plan". June 3, 1980.

Department of Justice, "Ten Year Energy Conservation Plan For Buildings". May 1980.

Department of Labor, "Ten Year Building Plan". May 1980.

National Aeronautics and Space Administration. "Energy Management Buildings Plan". May 1980.

Panama Canal Company. "Ten Year Buildings Plan". August 7, 1980.

Tennessee Valley Authority. "Ten Year Plan For Reduction of Energy Use". July $3,1980$.

Department of Treasury, "Buildings Plan For Conservation of Energy". June 16, 1980.

Department of Transportation, "Ten Year Energy Conservation for Buildings". August 1980.

United States Postal Service. "Energy Management Program: Ten Year Buildings Plan". May 1980.

Veteran's Administration. "Energy Management Plan (1975-1985)". May 1980.

\section{Legislative References}

"Compilation of Energy-Related Legislation," Volume III - Energy Conservation, Organization, and Related Matter, Part A; Energy Policy and Conservation Act p. 5-158; National Energy Conservation and Policy Act p. 207-278. Washington, D.C., Government Printing office, August 1979. 


\section{United States}

Department of Energy

Washington, D.C. 20585
THIRD - CLASS MAIL. POSTAGE \& FEES PAID

U.S. DEPT. OF ENERGY

PERMIT NO. G 20

THIRD CLASS MAIL

Official Business

Penalty for Private Use, $\$ 300$ 